\title{
Preface to the Thematic Section: Mine Tailings: Problem or Opportunity? Towards a Combined Remediation and Resource Recovery Approach
}

\author{
Lieven Machiels $^{1} \cdot$ Max Frenzel $^{2} \cdot$ Daniel Goldmann $^{3} \cdot$ Mirja Illikainen $^{4} \cdot$ Stephan Pfister $^{5}$
}

๑ The Minerals, Metals \& Materials Society 2021, corrected publication 2021

Since the earliest days of the Industrial Revolution, Europe has been discarding vast quantities of mining residues, commonly referred to as "extractive waste." Even today, $900 \mathrm{Mton} / \mathrm{year}$ of extractive waste is being generated and stored in tailing facilities or ponds. This $900 \mathrm{Mton} /$ year figure corresponds to $26 \%$ of the EU's current waste output [1]. Without proper management, tailing ponds can lead to environmental problems, ranging from acid mine drainage (AMD) and water contamination to dam bursts and flooding, air pollution, and soil erosion and contamination [2].

Despite the fact that industry has strongly invested in the development of state-of-the-art "tailings storage facilities" (TSFs) that are equipped with environmental protection technologies-in line with the Mining Waste Directive (2006/21/EC EU) - the potential occurrence of these environmental problems could erode society's acceptance of and trust in sustainable metal production in the EU and beyond.

The main challenge lies with the "sulfidic tailings," which are particularly prone to AMD [2]. Sulfidic tailings mainly arise during the production of copper, zinc, and lead from

Lieven Machiels

lieven.machiels@kuleuven.be

1 Department of Chemistry, KU Leuven, Celestijnenlaan 200F Heverlee, box 2404, B-3001 Leuven, Belgium

2 Helmholtz Institute Freiberg for Resource Technology, Freiberg, Germany

3 Department of Mineral and Waste Processing, Institute of Mineral and Waste Processing, Waste Disposal and Geomechanics, Clausthal University of Technology, Walther-Nernst-Str. 9, 38678 Clausthal-Zellerfeld, Germany

4 Fiber and Particle Engineering Research Unit, University of Oulu, P.O. Box 4300, 90570 Oulu, Finland

5 Group for Ecological Systems Design, Institute of Environmental Engineering, ETH Zurich, John-vonNeumann-Weg 9, Zurich, Switzerland sulfidic $\mathrm{Cu}(-\mathrm{Zn}), \mathrm{Cu}-\mathrm{Pb}-\mathrm{Zn}, \mathrm{Zn}, \mathrm{Pb}$, or $\mathrm{Pb}-\mathrm{Zn}$ mines, which are widespread in Europe. Sulfidic tailings also represent the largest volumes of tailings in Europe: rough estimations reveal a yearly production of $500+$ Mton and historical stocks of $28,000+$ Mton.

Although the EU mining industry has spared no efforts to improve its environmental performance, the dominant extractive-waste management philosophy is still a conservative one, as its primary concern is to minimize environmental risks through a containment strategy. Resource recovery and/or reprocessing of tailings only occurs in a handful of cases in the EU. On the other hand, the European Innovation Partnership (EIP) on Raw Materials, which was set up to address Europe's precarious dependence on critical-metal imports, has been highlighting that Europe's potential for metal recovery from its extractive waste is "underexploited." The European Innovation Partnership (EIP) Raw Materials have, therefore, launched a "call to arms" to transform the extractive-waste problem into a resource-recovery opportunity, earmarking mining residues as one of the key waste streams in Europe for future valorization. Indeed, these residues contain many raw materials that are currently not recovered, including materials that are considered critical for the EU economy.

In a response to the European Innovation Partnership (EIPs) "call to arms," the European training network (H2020 MSCA ITN) for the remediation and reprocessing of sulfidic mining waste sites (SULTAN) was set up (https://etn-sultan. $\mathrm{eu} /$ ). The objective of SULTAN is twofold, i.e., (1) mitigating environmental risks intrinsic to sulfidic tailings, and (2) recovering both valuable and critical raw materials from Europe's tailings. The current thematic section comprises 10 research papers on the different aspects of the SULTAN near-zero-waste reprocessing value chain for Europe's extractive waste. 
The overall SULTAN project concept is presented in Fig. 1. Following a diversified and sustainable supply-chain approach, SULTAN develops novel methodologies to study the resource potential of Europe's most important tailing families $(\mathrm{Cu}-\mathrm{Zn}, \mathrm{Zn}-\mathrm{Pb}$, and $\mathrm{Cu}-\mathrm{Zn}-\mathrm{Pb}$ tailings, WP1) and explores eco-friendly mining chemicals that can be integrated into newly developed critical-metal extraction/ recovery set-ups (WP2). SULTAN simultaneously targets clean(ed) tailing residues that can be valorized in diverse, high-added value applications, including inorganic polymers, green cements, and ceramics (WP3). To be able to corroborate the environmental and economic benefits of future tailings-reprocessing flow sheets based on the knowhow developed in WP1-3, WP4 develops a novel environmental assessment methodology that is custom designed for tailings. To evaluate the SULTAN near-zero-waste-processing scheme, three case studies have been analyzed, being (1) the historical $\mathrm{Zn}-\mathrm{Pb}$ mining and metallurgical processing area in Plombières, Belgium; (2) the active $\mathrm{Cu}-\mathrm{Zn}$ Neves Corvo mine in Portugal; and (3) the historical $\mathrm{Cu}-\mathrm{Zn}-\mathrm{Pb}$ tailings in the Freiberg district, Germany. As the case studies strongly vary, with respect to both technical aspects

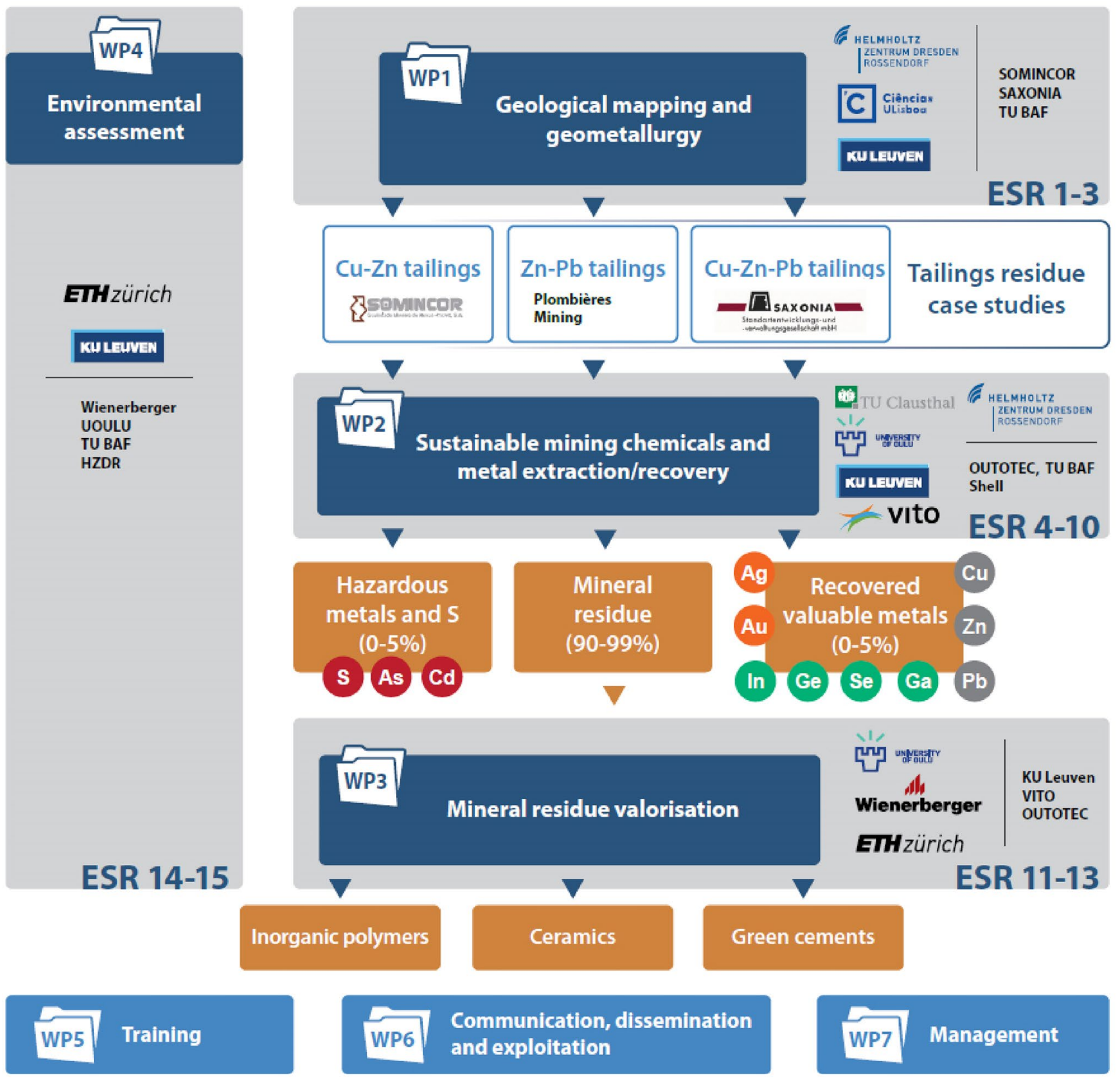

Fig. 1 General SULTAN flow diagram. ESR refers to "early-stage researcher," WP refers to "work package" 
(valuable/hazardous metal types and content, mineralogy, grain size, etc.) as non-technical aspects (size, ownership, land protection status, legislation for re-mining), a site-specific approach is needed to evaluate the re-mining potential. While in this thematic section results of the Plombières and Neves Corvo case studies are presented, results from the Freiberg case study will be published separately in future contributions.

\section{The Plombières Case-An Example of a Small-Scale Historical Tailing Site}

Three papers in the thematic section study different aspects of the assessment of the re-mining potential of the Plombières site in Belgium [3-5]. The Plombières site composes an area of different historical mining and metallurgical processing sites. Metal production lasted until the early twentieth century. The extractive waste comprises a variety of mineral processing and metallurgical residues, originating from the production of lead and zinc through the treatment of local ores and, in a later stage, imported ores. Today, the mining area of Plombières is a natural reserve. For the current study, an extractive waste depositional basin ("tailing pond") covering a surface area of $8000 \mathrm{~m}^{2}$ was selected [3]. Bevandić et al. previously constructed a 3D model describing the spatial variability of tailings [6]. Drillings were performed throughout the tailing pond, and variations in chemistry, mineralogy, and grain size were determined. Data were used to construct a 3D model composing four different layers, i.e., soil, metallurgical waste, brown, and yellow tailings. Cappuyns et al. (this issue) perform an indepth chemical and mineralogical characterization allowing to estimate the metal recovery potential and to evaluate the risk of hazardous metal mobilization [4]. Bevandić et al. (this issue) determine the metal leachability, applying different hydrometallurgical treatments on the metallurgical waste as well as on the brown and yellow tailings [3]. Finally, Veiga Simão et al. assess the potential of using the yellow tailings in ceramic products and successfully produce tailing-containing roof tiles (5\%), inner-wall blocks (10\%), and pavers (10 and 20\%), in compliance with production processes, product quality, and environmental regulations [5].

These studies deliver an important contribution to the methodology development for the assessment of the re-mining potential of historical mining sites while also showing the potential for the re-mining of this particular site. Nevertheless, important showstoppers can be identified, which inhibit the re-mining of this particular site. While the total volume of extractive waste in the area might be significant, the average size of the individual sites scattered throughout the area is very small. Apart from the lack of economies of scale, the large heterogeneity even within individual sites makes reprocessing even more challenging. Concurrently, non-technical barriers, such as the categorization of the site as a natural reserve and associated Social License to Operate issues, impede the re-mining to come to fruition.

In the case of historic tailings sites, a decision to actually re-mine such smaller sites is likely only possible if the site poses acute environmental and/or health risks. While present-day tailings are in general well protected in stateof-the-art tailing storage facilities, historical tailings typically lack the required safety and environmental protection measures. If these risks require the removal of the tailings to state-of-the-art tailing storage facilities or landfills, a remining approach could still be considered as an alternative. Resource recovery can then partially compensate for the remediation costs.

\section{The Neves Corvo Case-An Example of a Large-Scale Present-Day Tailings Storage Facility}

Six papers of the thematic section are dedicated to different aspects of the characterization, metal extraction, and valorization of the mineral fraction of the Neves Corvo extractive waste [7-12]. Neves Corvo is an underground $\mathrm{Cu}-\mathrm{Zn}$ mine located in Southern Portugal. Within SULTAN, both waste rock from the mining operations as well as tailings from the flotation operations to produce copper and zinc concentrates are studied. The size of the operation is obvious from the amount of tailings and waste rock deposited in the Cerro do Lobo Tailings Management Facility, which is estimated to comprise 47 Mton [7]. As for the Plombières case, a detailed characterization study is performed (Gomez Escobar et al., this issue) [7]. In a future communication, this study will be extended to a 3D model describing the spatial variability of the Cerro de Lobo tailings storage facility. As these tailings contain considerable amounts of copper and zinc, reprocessing in view of metal recovery can be considered.

Different mineral processing and metallurgical methods are evaluated in this issue. Braga de Carvalho et al. (this issue) study flocculation of ultra-fine particles, i.e., the formation of larger aggregates of specific minerals [13]. This flocculation process can improve the recovery of the target metals in ultra-fine particles through flotation. While pure minerals were used in the current study, in a next step, the technique will be applied to sulfidic tailings. Schueler et al. (this issue) apply sulfuric acid and chloride leaching for the recovery of copper, zinc, and lead [8]. Everaert et al. (this issue) apply an alternative method to recover target metals: they explore a roasting process followed by ammoniacal leaching [9]. Subsequently, Xanthopoulos et al. (this issue) use ion flotation techniques for the recovery of copper from 
ammoniacal leachates [10]. In a subsequent step, ion flotation collectors are regenerated and reused in the next ion flotation cycle [11]. Finally, Niu et al. use the Neves Corvo waste rock to successfully produce inorganic polymer products, indicating that also bulk applications of the waste rock in construction materials can be considered [12].

Compared to the Plombières case, the reprocessing of the Neves Corvo tailings seems to be more realistic. The sheer volume of the Neves Corvo tailings facilitates the reprocessing at large scale, triggering favorable economies of scale. Furthermore, heterogeneity is expected to be much smaller. Concurrently, from a legislative and Social License to Operate perspective, this case is more straightforward as it is already categorized as a site of mining activity, in contrast with the Plombières tailings that are located in a natural reserve. If the process economics for the recovery of copper and zinc are not satisfactory, other aspects could contribute to a positive business case, such as the recovery of sulfur for sulfuric acid production, or the use of the mineral fraction after metal recovery in construction applications. In this way, a near-zero-waste treatment scheme could be developed, which would also mean that the tailing storage facility can be strongly reduced in size, while mitigating long-term risks such as AMD. More detailed determination of the 3D distribution of the metals in the tailing pond (to produce a resource model), combined with piloting of promising technologies and flowsheets, would be needed to turn the re-mining of tailings into a successful business case. Such an endeavor would support Europe's coveted circular economy targets.

Acknowledgements The SULTAN project has received funding from the European Community's Horizon 2020 Programme under Grant Agreement No. 812580 (MSCA- ETN SULTAN). The authors acknowledge Dr. Peter Tom Jones (SIM ${ }^{2}$ KU Leuven) for his text editing and suggestions.

\section{References}

1. Eurostat (2018) Waste statistics. https://ec.europa.eu/eurostat/stati stics-explained/index.php?title=Waste_statistics\#Total_waste_ generation

2. Lottermoser B.G. (2010) Sulfidic Mine Wastes. In: Mine Wastes. Springer, Berlin, Heidelberg. https://doi.org/10.1007/ 978-3-642-12419-8 2
3. Bevandić S, Xanthopoulos P, Muchez P (2021) Chemical leaching of sulfidic mining waste, Plombières tailings pond, Eastern Belgium: insights from a mineralogical approach. J Sustain Metall. https://doi.org/10.1007/s40831-021-00445-0

4. Cappuyns V, Campen VA, Bevandić S, Helser J, Muchez P (2021) Characterization of mine waste from a former $\mathrm{Pb}-\mathrm{Zn}$ mining site: reactivity of minerals during sequential extractions. J Sustain Metall. https://doi.org/10.1007/s40831-021-00455-y

5. Veiga Simão F, Chambart H, Vandemeulebroeke L, Nielsen P, Cappuyns V (2021) Turning mine waste into a ceramic resource: Plombières tailing Case. J Sustain Metall. https://doi.org/10.1007/ s40831-021-00442-3

6. Bevandić S, Blannin R, Vander Auwera J, Delmelle N, Caterina D, Nguyen F, Muchez P (2021) Geochemical and mineralogical characterisation of historic $\mathrm{Zn}-\mathrm{Pb}$ mine waste, Plombieres, East Belgium. Minerals 11:28. https://doi.org/10.3390/min11010028

7. Escobar AG, Relvas JMRS, Pinto ÁMM, Oliveira M (2021) Physical-chemical characterization of the Neves Corvo extractive mine residues: a perspective towards future mining and reprocessing of sulfidic tailings. J Sustain Metall. https://doi.org/10.1007/ s40831-021-00428-1

8. Schueler TA, de Aguiar PF, Vera YM, Goldmann D (2021) Leaching of $\mathrm{Cu}, \mathrm{Zn}$, and $\mathrm{Pb}$ from sulfidic tailings under the use of sulfuric acid and chloride solutions. J Sustain Metall. https://doi.org/ 10.1007/s40831-021-00446-z

9. Everaert M, Guerrero F, Kamariah N, Spooren J (2021) Fundamental insights in alcoholic ammoniacal systems for selective solvometallurgical extraction of $\mathrm{Cu}, \mathrm{Zn}$, and $\mathrm{Pb}$ from tailings. J Sustain Metall. https://doi.org/10.1007/s40831-021-00382-y

10. Xanthopoulos P, Kalebić D, Kamariah N, Bussé J, Dehaen W, Spooren J, Binnemans K (2021) Recovery of copper from ammoniacal leachates by ion flotation. J Sustain Metall. https://doi.org/ 10.1007/s40831-021-00363-1

11. Xanthopoulos P, Binnemans K (2021) Closing the loop in ion flotation: recovery of copper, regeneration and reuse of collector from the foam phase by a solvometallurgical process. J Sustain Metall. https://doi.org/10.1007/s40831-021-00463-y

12. Niu H, Adrianto LR, Escobar AG, et al (2021) Potential of mechanochemically activated sulfidic mining waste rock for alkali activation. J Sustain Metall. https://doi.org/10.1007/ s40831-021-00466-9

13. Braga C, de Carvalho AL, Ludovici F, Goldmann D, Silva AC, Liimatainen H (2021) Silylated thiol-containing cellulose nanofibers as a bio-based flocculation agent for ultrafine mineral particles of chalcopyrite and pyrite. J Sustain Metall. https://doi.org/10. 1007/s40831-021-00439-y

Publisher's Note Springer Nature remains neutral with regard to jurisdictional claims in published maps and institutional affiliations. 